\title{
Some Aspects of Photovoltaic/Thermal Systems Operation in Central European Climate
}

\author{
Dorota Chwieduk* (D) and Jaroslaw Bigorajski \\ Institute of Heat Engineering, Warsaw University of Technology, Warszawa, Poland
}

Received: 7 July 2021 / Received in final form: 20 September 2021 / Accepted: 20 September 2021

\begin{abstract}
The paper analyses the operation of a photovoltaic/thermal system in a single family house in a central European climate through simulation studies. The PV/T system is used for DHW heating and electricity generation. Glazed and unglazed modules are considered. Effective utilization of solar energy for heating purposes requires the use of heat storage, which is particularly visible not only in cold, but also in moderates climates. Consequently, the operation of solar systems is more complex, different modes of operation are possible to provide heat or electricity, or both. Possible modes of operation were appropriately modeled and the obtained energy gains were analyzed. When modeling the heat storage process, the heat stratification effect in the storage tank was taken into account. Monthly shares of solar energy in providing DHW heating energy and electricity for all months of the year are presented. The glazed modules can fully cover the DHW demand during 5 warm months, but they cannot cover the electricity demand. The share of electricity provided by PV can vary from $67 \%$ to $93 \%$. On the contrary, in the case of unglazed PV/T modules during these 5 months the share of thermal demand can be covered only from $62 \%$ to $90 \%$, but the electricity demand can by covered fully. In winter there is no significant solar thermal energy gained in both cases. Unglazed PV/T modules should be used in central European climate, if electricity generation is a priority. If DHW heating is equally important, then their operation should be coupled with glazed thermal collectors.
\end{abstract}

\section{Introduction}

One of the important factors influencing the effective operation of PV modules is the decrease in their electrical efficiency with increase in their temperature. The temperature increase is due to the fact that not all the absorbed solar radiation is converted into electricity by the photovoltaic effect. The rest of absorbed energy causes an increase in the internal energy and as a result the temperature of the body (PV cell and module) increases. Such a situation becomes a significant problem in summer, even in moderate climates. Producers of PV modules presenting their energy performance give a value for the temperature efficiency factor or temperature power factor. Such factors are expressed in $[\% / \mathrm{K}]$ and $[\%$ of $\mathrm{W} / \mathrm{K}]$ respectively and they show how much efficiency (as a percentage) of the $\mathrm{PV}$ module decreases with every $1 \mathrm{~K}$ increase of temperature or how much power (as a percentage) is lost for every $1 \mathrm{~K}$ temperature increase.

There is a need to cool the PV modules during their operation. PV modules used on a large scale are installed on

\footnotetext{
* e-mail: dchwied@itc.pw.edu.pl
}

a supporting structure and they have direct contact to ambient air from both sides: front and back. They can lose heat to the surroundings through convection, mainly forced by the wind. However, when there is no wind and the ambient air temperature is high the temperature of the PV modules can increase noticeably. A worse situation can be seen in the case of $\mathrm{PV}$ modules attached to the roof or facade of a building, even if there is free space between the roof tiles and rear of the modules. The free air gap allows ambient air to flow underneath the module, but the air flow is usually not strong enough to cool the module sufficiently. The worst situation takes place when BIPV - Building Integrated Photovoltaics technology is used and the PV modules are directly incorporated into a wall or roof structure. In this case the rear surfaces of the PV modules stay in direct contact with the building and are not cooled by the ambient air. The PV module temperature can rise quickly to a high level.

There are different technologies available to reduce temperature of the PV modules. However, there is no standard method to assure their effective cooling. The simplest method is to spray water onto the hot surface of the PV module [1-3]. Both sides of the PV modules, the front and the rear, can be sprayed by the cold water and 
the efficiency of the PV modules can be kept at the standard level (according to values determined for STC - Standard Test Conditions), but there is often a problem of lack of water.

Sometimes the rear of the module contains fins to extend the surface having direct contact with the ambient surrounding. As a result the heat transfer (cooling effect) between the rear of the module and the ambient air is more intensive, sometimes even doubled [4-7]. Chen and others [6] indicate that thanks to application of fins the average efficiency of photovoltaic module can be bigger by $0.3-1.8 \%$ comparing with the same modules without fins tested in the same weather conditions. Using fins is a relatively simple method, but it requires specific design depending on the location of the modules and changes in manufacturing process of the PV modules.

Another method considered for the cooling of PV modules is to apply Peltier modules [7-9]. The Peltier module can be attached to the rear of the PV module. To operate and cool the PV module the Peltier module needs electricity, which can be produced by the PV cells. The cooling effect increases with the increase of electric current. However, the electricity needed for the operation of the Peltier module can be quite large, and energy consumed by the Peltier modules can be nearly the same as the energy gains obtained through the cooling effect. Because of that, interest in developing this technology is small.

Another innovative method is to use a layer of Phase Change Material - PCM attached to the rear surface of the module $[4,7,10-14]$. The melting point of the PCM should be carefully selected with regard to the type of PV material and expected operating temperature of the PV module. Browne, Norton and McCormack [10,11], tested and analyzed this method using different PCMs and validated results of simulation studies with experimental indoor and outdoor tests. Stropnik and Stritih [14] developed numerical simulation studies of the operation of the PV panels with and without PCM at the rear of the PV modules and calculated the electrical energy produced by the two types of the PV systems to differ by $7.3 \%$ annually. Thus application of PCMs can be seen as a promising alternative for cooling of the PV modules and keeping high their electrical efficiency.

One possible way of solving the problem of too high a temperature in $\mathrm{PV}$ modules is to use $\mathrm{PV} / \mathrm{T}$ - PhotoVoltaic/ Thermal modules. They combine the functions of supplying both electricity and heat. In PV/T modules the heat is a kind of waste heat or "complementary" energy product. Therefore, a $\mathrm{PV} / \mathrm{T}$ module might be called a solar combined energy device (system). Such a technology as innovative new solution of co-generation electricity and heat is a topic of the paper with regard to its application in central European climate.

\section{Photovoltaic/thermal modules concept in research studies}

This chapter presents a brief overview and history of the $\mathrm{PV} / \mathrm{T}$ - PhotoVoltaic/Thermal modules with focus on research studies developed for this technology. The concept of the $\mathrm{PV} / \mathrm{T}$ module was presented for the first time by Wolf in 1976 [15]. Wolf analyzed operation of $\mathrm{PV} / \mathrm{T}$ modules in single family houses and assumed that the solar energy reaching the thermal part of the module is equal to $90 \%$ of hemisphere solar radiation incident on the front surface of the PV/T module. Other pioneers in design and performance of air and water $\mathrm{PV} / \mathrm{T}$ modules were Kern and Russel [16] and Hendrie [17]. On a base of experimental studies on the operation of water and air $\mathrm{PV} / \mathrm{T}$ modules Hendrie got the maximum thermal efficiency of the $\mathrm{PV} / \mathrm{T}$ modules at level of $40.4 \%$ and $32.9 \%$, respectively. As a result she recommended application of water $\mathrm{PV} / \mathrm{T}$ modules, if gaining the thermal energy for heating purposes is most important. In 1979 Florschueltz started mathematical modelling of the operation and performance of the $\mathrm{PV} / \mathrm{T}$ modules [18]. He proposed to model the thermal part of the $\mathrm{PV} / \mathrm{T}$ module in the same way as the thermal solar collector is modeled and to use the Hottel-Whillier-Bliss fundamental model [19] as its basis.

In the 1980s researchers working on $\mathrm{PV} / \mathrm{T}$ modules mainly dealt with flat plate $\mathrm{PV} / \mathrm{T}$ modules and conducted experimental studies validating the simulation results of the PV/T operation and energy performance [20-23]. At that time also some research studies on the $\mathrm{PV} / \mathrm{T}$ concentrating modules started [24]. In those days two cooling media of the $\mathrm{PV} / \mathrm{T}$ modules were considered, air and water (however refrigerants were also analyzed [25]. Fundamentals of the PV/T module operation, a description of the different designs and structures of $\mathrm{PV} / \mathrm{T}$ 's and their applications, together with the history of the development of this technology have been described in comprehensive way by Tripanagnostopolous [26].

Since the end of the past century BIPV - Building Integrated Photovoltaics as a new technology has been developed (mainly in Germany). Very quickly it was seen that such a technology was not very good for the electrical efficiency of the PV cells, when PV modules were incorporated directly into the structure of a building. In such a situation there is a lack of the natural cooling effect due to ambient air flow at the rear of the modules and the temperature of the BIPV modules can be much higher than the temperature of the PV modules installed on a roof (with a cavity between the roof and the rear of the module) or on the ground mounted supporting structure. As a result the efficiency of photo - electric conversion decreases. Due to this fact interest in research on air $\mathrm{PV} / \mathrm{T}$ modules increased.

The air BIPV/T - Building Integrated Photovoltaic/ Thermal technology can assure in a relatively simple way the effective cooling effect of the PV modules $[6,26]$. In the case of the BIPV/T systems the PV modules constitute the external layer of a building façade. There is a free space between the rear of the modules and the wall. Air can flow through such a cavity, cooling the modules or a heat exchanger (in a form of vertical ducts), which can be coupled with the rear of the modules, as in regular solar thermal collectors.

Air PV/T modules are relatively simple in construction and operation, and as a result less expensive. Up to now most of the research studies have been focused on analysis of the operation of the air $\mathrm{PV} / \mathrm{T}$ modules and determination 

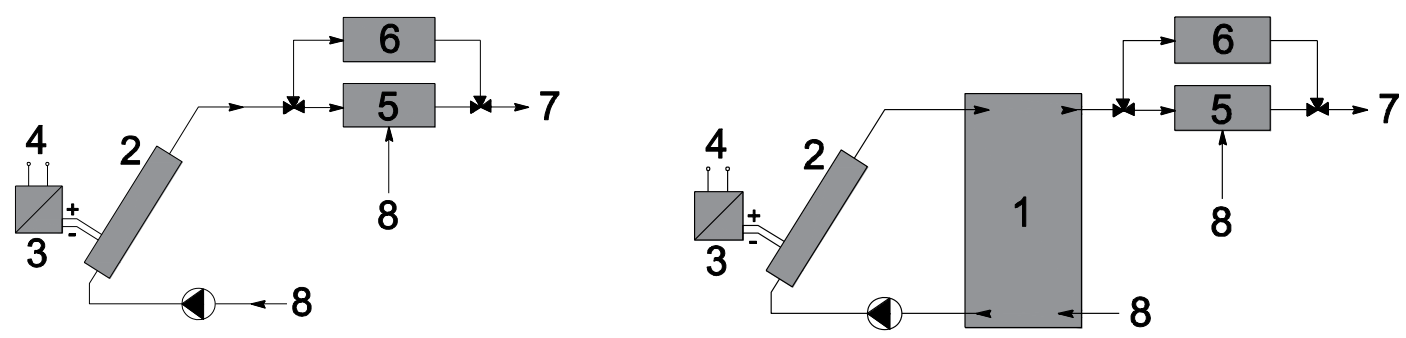

1 - buffer water storage tank

2 - $\mathrm{PV} / \mathrm{T}$ module

5- DHW tank

3 - inverter with a function to convert DC to AC

4 - inverter with a function to synchronize the

6 - auxiliary heater

7 - outlet to the DHW system

parameters of electric energy produced with

8 - inlet of cold water the parameters of the grid

Fig. 1. PV/T systems for Domestic Hot Water heating and electricity production, operating directly in hot climates without storage tank - left side and indirectly in moderate climates with a storage tank - right side.

of their energy performance [26-30]. There are far fewer papers on the operation and performance of water $\mathrm{PV} / \mathrm{T}$ modules [21-24], however an interest in this technology has been growing recently [31-34]. A roadmap for the technological advancement of hybrid $\mathrm{PV} / \mathrm{T}$ collectors has been published in 2018 [35]. The paper presents what can be done to make this technology competitive with other types of solar energy receivers with regard to the central European climate.

\section{General remarks of operation and performance of solar heating and $\mathrm{PV} / \mathrm{T}$ systems}

It is necessary to underline, that all studies in last century, both numerical simulation and experimental tests, were conducted for PV/T modules only. The complete PV/T system supplying heating energy and electricity are discussed quite rarely [36-39].

$\mathrm{PV} / \mathrm{T}$ modules are usually used directly - apart from producing electricity they utilize the "waste" thermal energy to directly heat the water passing through them. In this way it assures the cooling effect of the module at the same time. In this case the $\mathrm{PV} / \mathrm{T}$ module works as the main heating device (passive or active - without or with a pump respectively) with water as the working fluid in an open loop simplified Domestic Hot Water - DHW system presented in Figure 1. Open loop PV/T collector systems are especially recommended. Such a solution is very good for limiting the increase of temperature of the PV module, because the temperature of water at the inlet of the solar module is usually close to temperature of water from the mains. However, such an open loop system for DHW heating cannot be used in colder or even moderate climate.

In moderate climates an active solar system is usually used and the flow through the solar collector loop is forced by a pump [19]. The forced flow is necessary because in winter and quite often in spring and autumn the solar irradiance level is so small that conditions for creating sufficient natural convective force (high difference in density of the working fluid between the top and bottom of the solar collectors) do not appear. In addition, because of low ambient air temperature in winter (below zero) a nonfreezing mixture is used as the heat transfer fluid. It circulates through the solar collectors in a closed loop and transfers heat to the storage tank through a heat exchanger usually located at the bottom of the tank. The heated water can be used at the same time as it is collected and stored, or later, when there is a heat demand for the hot water, e.g., in a domestic hot water heating system when the inhabitants return home. The working fluid can circulate through the solar modules gaining heat, even if there is no use of hot water stored in the tank. In case of the $\mathrm{PV} / \mathrm{T}$ this is of course positive for solar thermal gains, but not advantageous for the operation of the PV module, because with every recirculation of the working fluid through the solar collectors the temperature at the inlet to the solar modules becomes higher. The temperature of the fluid could be so high that there is no real cooling effect and the efficiency of electric conversion drops significantly.

There is another problem typical of moderate and colder climates. Due to the low ambient air temperature during most months of the year, it is necessary to limit thermal energy losses from solar collectors. The reduction of heat losses from the front surface of a solar collector absorber is achieved through the application of a glazed cover. To reduce heat losses from the rear, thermal insulation is used. Reducing heat losses from solar collectors effectively helps to keep their temperature at a higher level. However, as mentioned above, it works against the need to keep the $\mathrm{PV} / \mathrm{T}$ temperature as low as possible when electricity is produced by the PV part of the modules. Thus there is an inescapable problem in how $\mathrm{PV} / \mathrm{T}$ modules in combined solar thermal and PV systems should operate and what might be the best solution for their design for applications in moderate climates. 
The $\mathrm{PV} / \mathrm{T}$ modules, as well as the solar thermal collectors, applied to Domestic Hot Water - DHW heating systems must cooperate with other elements of the systems, where a storage tank is the most important component and constitutes the focal point of the heating system. Usually, operation of a solar thermal system, including operation of a $\mathrm{PV} / \mathrm{T}$ system, does not only depend on weather conditions. The operation of the PV/T system depends on the design and configuration of the system components, including different possible modes of operation (control strategy), and on the energy consumption patterns: distribution in time of electricity and heating energy consumption by the end-users. Thus the components of $\mathrm{PV} / \mathrm{T}$ systems also operate in different conditions. Weather conditions influence the energy gains of the system, i.e., input to the storage tank, and heating energy consumption influences the thermal energy output of the storage tank. Therefore the energy performance of two identical solar systems operating under the same climatic conditions can be different when the energy consumption patterns vary.

It is very difficult to find any recommendations for $\mathrm{PV} / \mathrm{T}$ module design for specific climatic conditions and energy consumption patterns. The dynamics of operation of the whole $\mathrm{PV} / \mathrm{T}$ energy system under changing conditions of availability of solar energy and other weather parameters, and changing load patterns of thermal energy and electricity is very rarely analyzed in the literature. Usually the energy performance of $\mathrm{PV} / \mathrm{T}$ modules alone are presented and very rarely of the whole system.

As is known and well documented, liquid active solar heating systems in moderate climates should be equipped with glazed solar thermal collectors for their effective operation, keeping the solar energy fraction high while supplying heat to the end-user. Standard solar thermal collectors are glazed to reduce heat losses and to assure higher useful thermal energy gains. However, the transparent cover is not necessary or even not recommended for the PV modules, because it causes higher optical losses and does not allow the front side of the module to be cooled down by the natural air flow caused by the wind. But there are no guidelines for $\mathrm{PV} / \mathrm{T}$ modules design for application in moderate and colder climates.

Different types of the $\mathrm{PV} / \mathrm{T}$ modules are tested in standard testing conditions to determine their thermal and electrical efficiency curves as a function of so called the reduced temperature (ratio of working fluid temperature in the module and solar irradiance). However, such $\mathrm{PV} / \mathrm{T}$ module efficiency test results do not really correspond to conditions in which the whole system and its elements operate. What more nearly all studies are focused on low latitude countries, where solar irradiance, as well as ambient air temperature are high, and $\mathrm{PV} / \mathrm{T}$ modules operate in a direct way in open loop systems heating the DHW for direct use and cooling the module at the same time.

The paper presents the improvement of the thermal and electrical performance of the $\mathrm{PV} / \mathrm{T}$ system can be achieved in central European climate. The study performed are focused not only on electrical performance of the system but on thermal performance as well. Thermal energy gains are important for moderate climates (high latitude countries), where solar irradiation varies a lot during a short time span - a day and long time - annually.

\section{Analysis of operation and performance of a PV/T system for DHW heating and electricity generation at single family house in central European climate}

\subsection{Modes and main assumptions of the system operation}

The traditional $\mathrm{PV} / \mathrm{T}$ system used for direct heating of cold water from the mains with an open loop of solar collectors is presented in Figure 1 (left). It is characteristic that no storage tank is required. An indirect $\mathrm{PV} / \mathrm{T}$ system with a storage tank as considered in this paper, is shown in Figure 1 (right). It has been assumed that the same working fluid is circulating through solar modules as is stored in the tank, and that it is water. There is no heat exchanger in the storage tank.

In central European climate in winter the solar irradiance and ambient temperature are rather low. Therefore, it can be expected that in winter a $\mathrm{PV} / \mathrm{T}$ module can produce mainly electricity (photo-electric conversion takes place first and the rest of energy absorbed is converted into thermal energy). The amount of gained thermal energy can be very small or even neglected. In such a climate four main modes of operation are expected to be applied for the $\mathrm{PV} / \mathrm{T}$ systems and they are described briefly below.

The first mode is when solar energy is available (solar irradiance is above the minimum level and can create the photovoltaic effect in the $\mathrm{PV}$ cell) and the $\mathrm{PV} / \mathrm{T}$ module is working. Solar energy is collected and converted into electricity. Electricity can be used at the same location (in the house) or transmitted to the grid (through an inverter with functions of conversion $\mathrm{DC}$ to $\mathrm{AC}$ and synchronization of parameters of electric energy produced at the site by the PV modules with the required electric parameters of the grid). A working fluid circulates between solar collectors and the buffer storage tank transferring heat to the tank, but there is no use of the hot water stored in the tank (no heating demand). The temperature of working fluid in the $\mathrm{PV} / \mathrm{T}$ module and temperature of water in the buffer tank increases. The system operates when solar radiation is available, but the automatic control system can stop circulation of the fluid through the $\mathrm{PV} / \mathrm{T}$ modules, because of safety reason (e.g., temperature of water in the storage tank too high). When there is not enough electricity produced by the solar module to provide all energy needs required for operation of the domestic electric appliances and lighting then the electricity can be taken from the grid, since the considered $\mathrm{PV} / \mathrm{T}$ system is an on-grid system.

The second mode is used when the $\mathrm{PV} / \mathrm{T}$ module is working because of high solar irradiation. There are some sub-modes of operation of the rest of the $\mathrm{PV} / \mathrm{T}$ system that can happen under such solar radiation conditions. Electricity produced is used in the house or transmitted to the grid. Working fluid circulates through the solar 


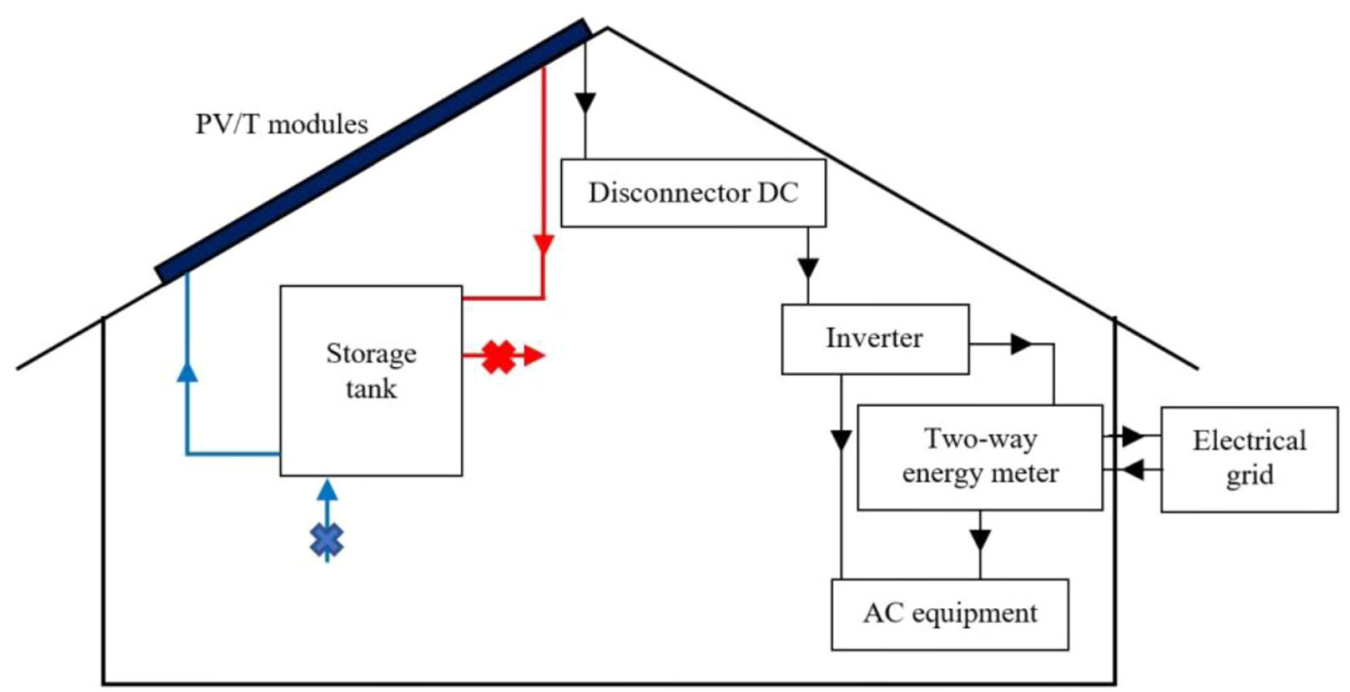

Fig. 2. Mode 1. Energy flows in the system: PV/T modules are working, solar energy is collected and converted into electricity and thermal energy, which is stored in a tank, no hot water is used by the end-user.

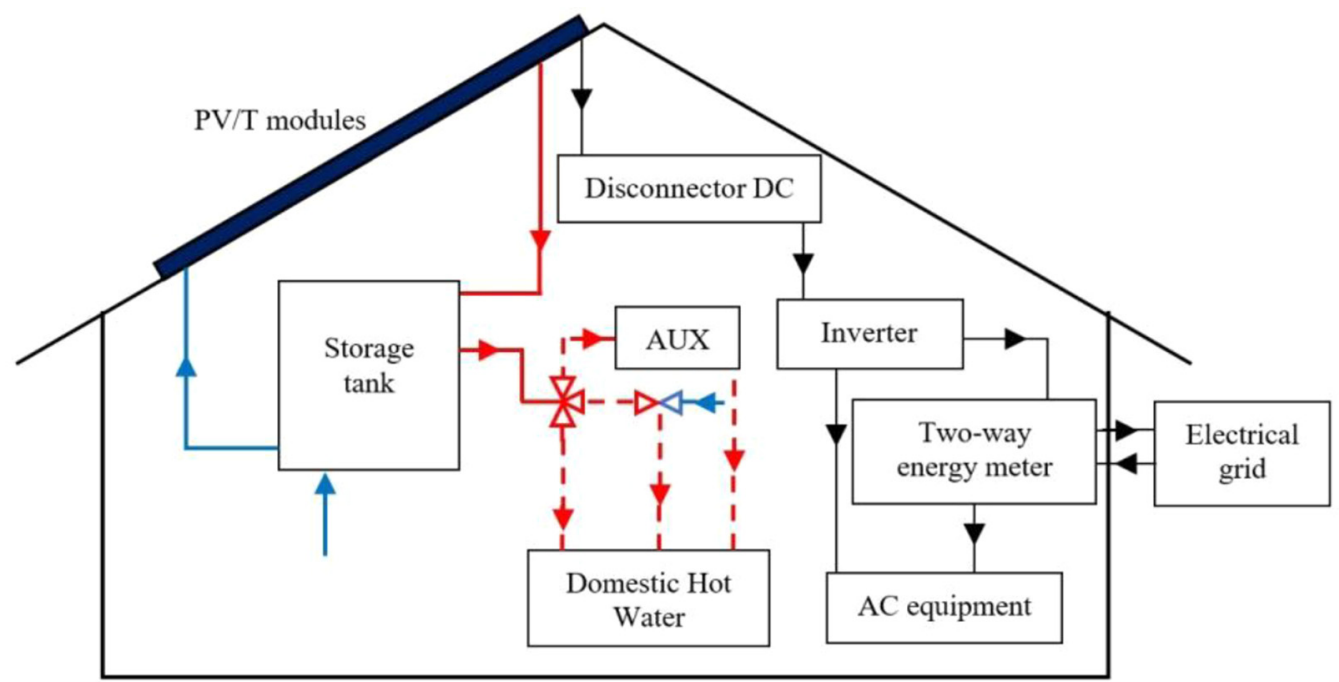

Fig. 3. Mode 2. Energy flows in the system during different sub-modes for DHW heating: PV/T modules are working, solar energy is collected and converted into electricity and into thermal energy, which is stored in a tank and used by the end-user.

modules and thermal energy is stored in a buffer storage tank and the heated water is used by the occupants. Depending on the solar radiation conditions and the demand for hot water needed by the occupants, the temperature of the working fluid and water in the tank can increase or decrease. Of course it is always possible to stop the flow through the solar modules for safety reasons. If the temperature of water flowing out of the buffer storage tank to the end-user through the DHW tank is too high it is possible to mix the hot water with the cold water from mains (in the DHW tank).

The third mode is applied when the $\mathrm{PV} / \mathrm{T}$ module is not working due to very low solar irradiance level or lack of any solar irradiance (night time), but hot water is extracted from the storage tank and is used directly or indirectly by end-users. When the temperature of the water in the buffer storage tank is lower than temperature required for the
DHW, then the auxiliary heater is applied. The preliminary heated water flows from the buffer storage tank to the auxiliary heater, and then being heated further it flows to the end user. Throughout this mode electricity is taken from the grid.

The fourth mode of operation is used when the modules produce only electricity, because any thermal energy gained is at too low a level to assure effective operation of the DHW heating system, and no solar heating can be accomplished. Throughout this mode the auxiliary heater supplies the DHW demand. However, if the water temperature in the buffer storage tank is above the minimum level (above $10^{\circ} \mathrm{C}$ ), then water can flow from it to the auxiliary heater, and then is heated further to be used by the occupants.

Figures 2-5 illustrate these different modes of the $\mathrm{PV} / \mathrm{T}$ system operation schematically. 


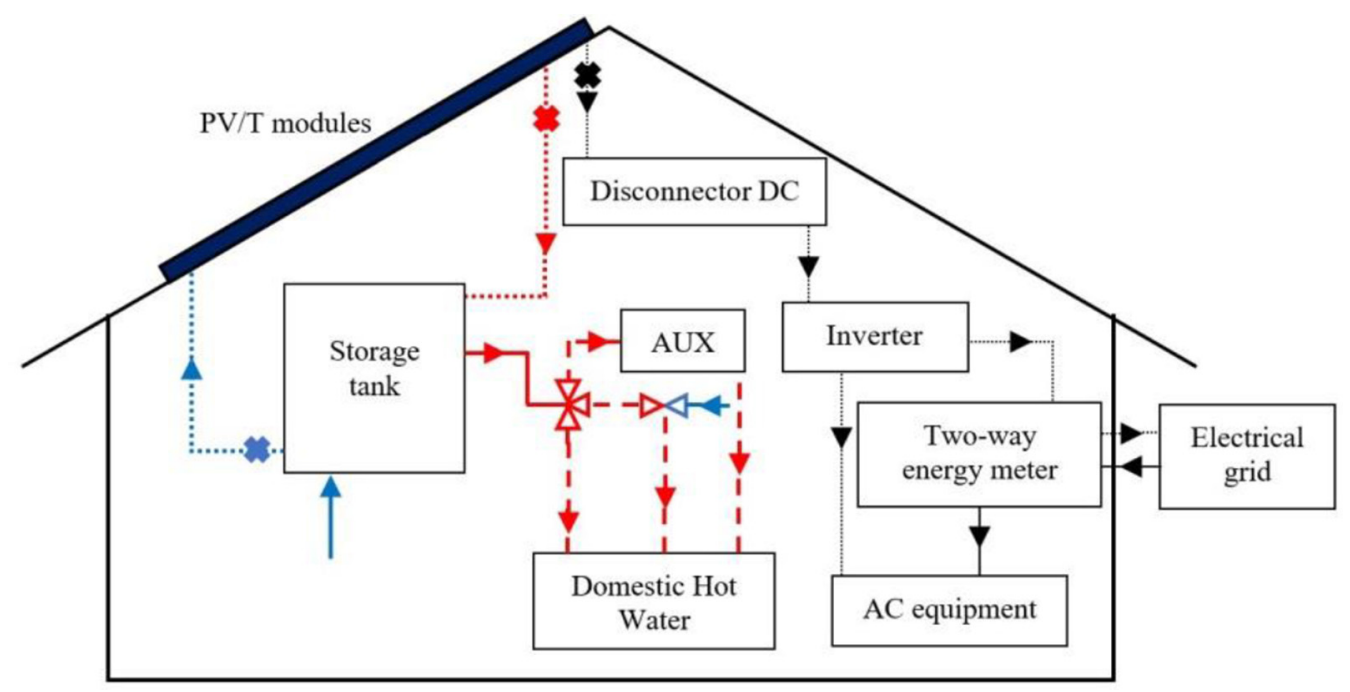

Fig. 4. Mode 3: Energy flows in the system. PV/T modules are not working: hot water is used by the end-user and different sub-modes for DHW heating are possible.

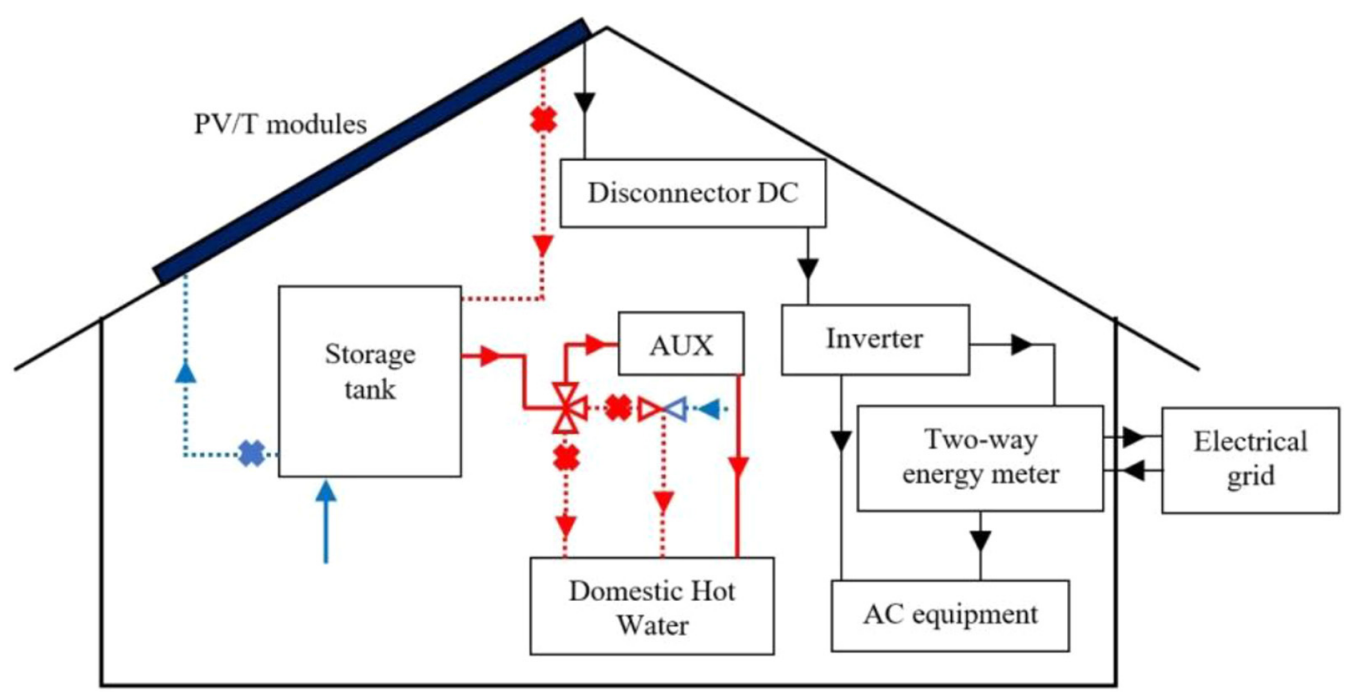

Fig. 5. Mode 4: Energy flows in the system. PV/T modules are generating only electricity, no solar heating can be accomplished and the auxiliary heater supplies the DHW demand.

Figures 2-5 show the energy flows in the system, between different components of the system and out of the system to the end-user and the grid (when there are some sub-modes for the specific mode of the operation, then dashed lines are used for the energy flows). All variants of the $\mathrm{PV} / \mathrm{T}$ system operation including all four modes can be described by relevant equations. Since a storage tank is a critical part of the considered $\mathrm{PV} / \mathrm{T}$ system it should be modelled in detail taking into account the thermal stratification effect and relevant equations describing this phenomena.

\subsection{Modelling of the system operation}

A mathematical model of water $\mathrm{PV} / \mathrm{T}$ active solar systems and their operation applied to Domestic Hot Water DHW heating and electricity production has been devel- oped. Simulation studies have been performed using a specially written numerical code (elaborated in Visual Basic). The code can simulate different sizes and configurations of $\mathrm{PV} / \mathrm{T}$ system components with different patterns of energy use and different weather conditions varying with time and the thermal stratification effect in the storage tank of the system [40,41]. The studies have been developed for central European climate, specifically for the Polish climate, where winters are cold with short day length, low solar irradiance and ambient air temperature, but summers are relatively hot with high solar irradiance, long day length and high temperature. Spring and autumn are characterized by moderate weather conditions. Four main modes of the system operation (described in a previous chapter) have been taken into account and modelled mathematically by using separate subroutines for each of the mode, and manage by the 
central subroutine to govern long-term dynamic operation of the DHW system.

To calculate solar irradiance available on inclined surfaces of the $\mathrm{PV} / \mathrm{T}$ modules it is necessary to have input data in form of global (i.e., direct and diffuse) and diffuse solar radiation on a horizontal surface at a given time for a given location. These data can be represented by hourly solar irradiation measured by meteorological stations for a given region. Then the solar irradiation on inclined surfaces can be calculated. Usually the isotropic solar radiation model for diffuse solar radiation, the Liu-Jordan model can be used [19]. According to this model, solar irradiance on an inclined surface of any solar receiver contains the three main components of solar radiation: direct, diffuse - scattered equally in the hemisphere, which gives isotropic distribution of the diffuse radiation (irradiance), and reflected from the ground (for a horizontal surface there is of course no solar radiation reflected from the ground). According to the Liu - Jordan model the hemispheric solar irradiance, i.e., the solar irradiance on a tilted surface, can be expressed as a function of direct and diffuse solar radiation on a horizontal surface corrected by adequate correction factors. These factors for diffuse and reflected solar irradiance are constant for a given inclination. Calculations of the correction factor for the direct solar irradiance are complicated. Usually the hourly values of this correction factor are determined on a base of the Hottel-Woertz method. However, it is necessary to notice that calculations of this correction factor must be done very carefully. There are some trends in the course of the function describing the distribution of the factor in time. Thus, unexpected high values can be obtained (especially for early morning hours), which give unrealistic values of direct solar irradiance on an inclined surface at that time of day. Having calculated solar irradiance incident on the inclined surface of a solar module the electrical and thermal energy rate gained in time can be calculated.

The electrical energy rate gained by the PV module depends strongly on solar irradiance, the temperature of the PV module and the design parameter of the module given by the transmittance - absorptance product. A high value of the transmittance - absorptance product means possible high values of the electrical efficiency and as a consequence the electrical energy produced. When there is no glazing cover the transmittance is ideal (has the maximum value of 1). Therefore, if possible, the PV modules should not be glazed.

The thermal energy gained by the $\mathrm{PV} / \mathrm{T}$ module can be described in a similar way as is done for the thermal solar collector. The useful heat rate can be calculated according to the Hottel-Whillier-Bliss model, which describes the energy balance of a solar thermal collector with assumption that the thermal capacity of the collector can be neglected. The heat rate gained by the $\mathrm{PV} / \mathrm{T}$ module is an energy input to the storage. The energy output refers to heating energy used for the Domestic Hot Water and to the heat losses out of the tank. The buffer storage tank utilizes the effect of the heat stratification and so the tank has to be modelled accordingly. Thus the tank is modelled as being divided into $n$ layers. The numbering of layers goes from the top to the bottom. The energy balance equations for every layer of the tank have been formulated. The stratification effect has been modelled by specifically defined control functions for the tank [19,40-42].

In the case of the $\mathrm{PV} / \mathrm{T}$ systems the mutual interaction between the photovoltaic and thermal parts of the $\mathrm{PV} / \mathrm{T}$ module is very important for the operation of the whole system. The temperature of water leaving the solar module is important for the heat gained and stored in the tank. With the increase of the temperature, more thermal energy can be stored. With the increase of the working fluid temperature the efficiency of thermal part of the system will increase. However, the electrical efficiency will decrease and less electricity can be generated. The link between the two parts of the PV/T module (photovoltaic and thermal) can be expressed through the relationship between the temperatures of these two parts. However, there is no standard formula for determination of the PV temperature in the PV module and the situation is much worse in the case of $\mathrm{PV} / \mathrm{T}$ modules. Many experimental and theoretical research on $\mathrm{PV} / \mathrm{T}$ module operation and energy performance were conducted by Tripanagnostopoulos. In literature his formula for determination of the temperature of the $\mathrm{PV}$ in the $\mathrm{PV} / \mathrm{T}$ module can be found [26]. Based on experimental tests (made under Tripanagnostopoulos supervision) and validation of the mathematical model of the $\mathrm{PV} / \mathrm{T}$ module operation Bigorajski proposed to modify the formula and introduced a $\mathrm{PV} / \mathrm{T}$ module cover factor with regard to number of transparent covers [41]. Such a modified formula was used for determination of the PV temperature in the $\mathrm{PV} / \mathrm{T}$ module and then to calculate electrical efficiency of the $\mathrm{PV} / \mathrm{T}$ modules. The thermal efficiency of the $\mathrm{PV} / \mathrm{T}$ module was determined as the ratio of the useful heat rate gained by the $\mathrm{PV} / \mathrm{T}$ modules and the solar irradiance on the tilted surface of the $\mathrm{PV} / \mathrm{T}$ modules.

\section{Some results of numerical simulation of the $\mathrm{PV} / \mathrm{T}$ system operation}

In this chapter some results of numerical simulation of the $\mathrm{PV} / \mathrm{T}$ system operation are presented. The results have been obtained using a numerical code formulated in Visual Basic to simulate the operation and energy efficiency of the $\mathrm{PV} / \mathrm{T}$ system in a single family houses [41]. The single family house is located in Warsaw and occupied by four people (each consuming 50 liters of hot water per day at a temperature of $45^{\circ} \mathrm{C}$, the mains cold water temperature is equal to $10^{\circ} \mathrm{C}$ ). A pattern of daily distribution of hot water consumption hour by hour has been assumed [43]. The pattern represents the worst conditions for the efficiency of the $\mathrm{PV} / \mathrm{T}$ modules, because there is no use of the hot water and electricity during the day time for 6 hours, when the solar irradiance is the highest. However, such a situation is typical for single family houses located in the suburbs of a city, when inhabitants work in the city and are absent from home during several hours of the day. During a day time thermal energy gained can be accumulated in a storage tank, but electricity must be sent to the grid (the system is not equipped with batteries to store the surplus of energy 


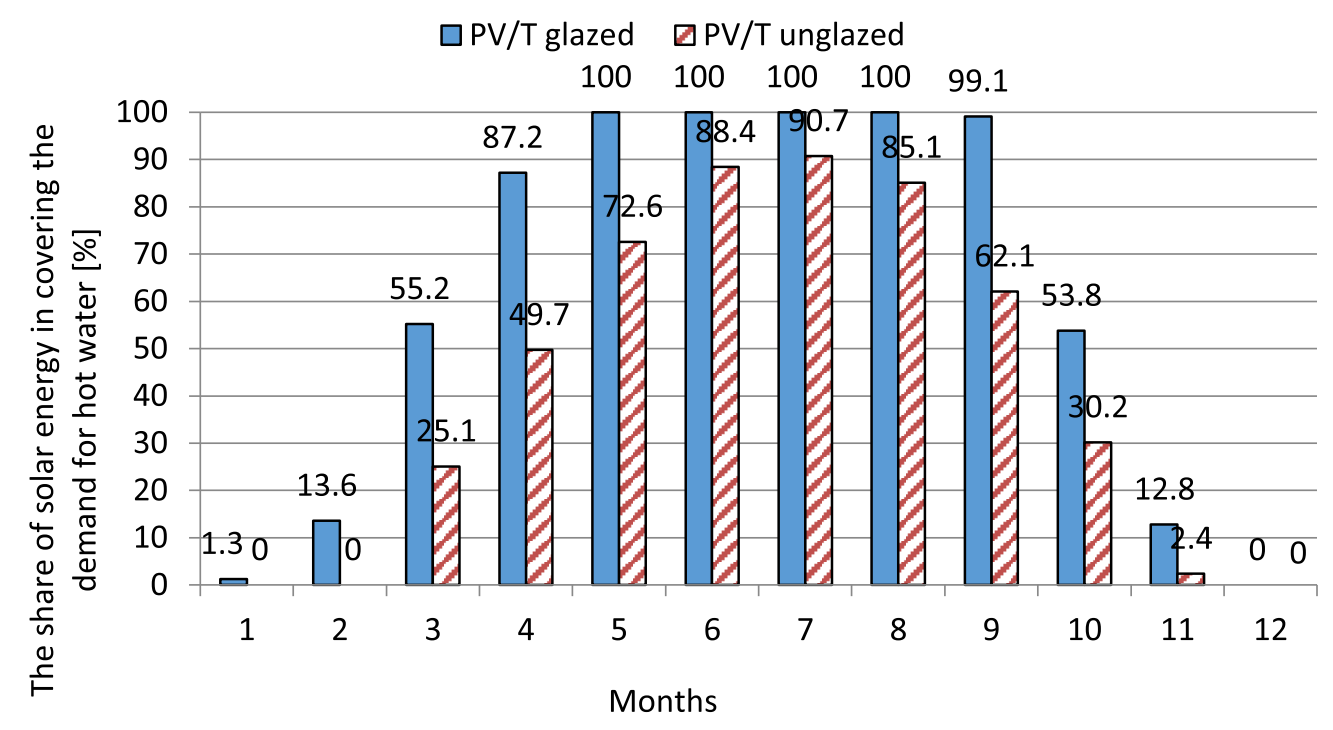

Fig. 6. The monthly share of solar energy in providing DHW heating energy.

gained). The grid is treated as virtual storage of $80 \%$ efficiency (according to the present regulation for micro energy systems based on renewables in Poland).

Simulation studies have been performed for different sizes of the $\mathrm{PV} / \mathrm{T}$ system used for $\mathrm{DHW}$ heating and electricity production for lighting and other domestic electrical appliances. The daily demand for DHW heating energy is just above $8 \mathrm{kWh}(8.15 \mathrm{kWh})$ and electricity demand slightly more $(8.22 \mathrm{kWh})$. It is assumed that the hourly patterns of electricity and heating energy (for DHW) consumption are the same for every day of the year. Energy for DHW heating is consumed mainly early in the morning (from 7 a.m. to 9 a.m.) and in the evening (from 5 p.m. to 11 p.m.), when also maximum electrical energy is consumed.

A $\mathrm{PV} / \mathrm{T}$ system of $3 \mathrm{~kW}_{\mathrm{p}}$ of installed capacity is considered in the paper, as the most typical size of PV system installed in Polish single family houses. Such installed power capacity corresponds to $22 \mathrm{~m}^{2}$ surface area of $\mathrm{PV} / \mathrm{T}$ modules and to $1.1 \mathrm{~m}^{3}$ of the storage volume. The modules are located on a south roof inclined at $30^{\circ}$. Operation of PV/T modules of two possible designs: with a cover (glazed) and without cover (unglazed) and their influence on solar energy thermal and electrical performance have been analyzed.

Figure 6 presents the monthly share of solar energy providing the DHW heating energy for all months of the year. It can be seen that for the five months from May to September the DHW demand is met fully by the system with covers. For the system without covers this is not possible and the maximum share of solar energy is in July then in June and accounts for about 90\%. In March and October the glazed system can provide more than $50 \%$ of demand, while the unglazed system can assure only $25-30 \%$ of the heating demand. As has been mentioned in winter the unglazed system does not work and for the glazed system the share of solar energy is so small that can be neglected for December and January, and for November and February it is about $13 \%$ only.
The monthly share of solar energy in providing DHW heating needs is very satisfactory for summer months, especially for systems with glazed modules. However, the distribution of the monthly share of the solar energy input to the system does not correspond directly to the average monthly thermal efficiency of the modules alone, as can be seen in Figure 7. The thermal efficiency of the solar modules is defined as a ratio of useful solar energy gained by solar collectors in given conditions to available solar radiation for the given period of time. Analyzing Figure 7 it can be seen that the considered unglazed $\mathrm{PV} / \mathrm{T}$ modules do not operate in winter, and averaged thermal efficiency of the glazed modules is very small. In summer the averaged thermal efficiency of unglazed $\mathrm{PV} / \mathrm{T}$ modules is the highest, just above $10 \%$. The glazed modules have the highest efficiency in spring and autumn, reaching $15 \%$ in spring and $18 \%$ in autumn. In summer the efficiency of these modules is lower and can be at a level of $12-14 \%$. Such a situation is caused by the assumed pattern of the daily DHW consumption, i.e., thermal energy is not consumed during most of the day when the solar irradiation is the highest. With no consumption of energy stored in the buffer tank the temperature of stored water increases. As a result the inlet temperature of water flowing to and through solar collectors also increases. Thus the heat losses of the solar modules increase and therefore the useful solar energy decreases. It is well known phenomena that in a case of flat plate solar collectors the temperature of the working fluid should be close to the ambient air temperature to reduce heat losses and increase the useful energy gains. With high solar irradiation and low useful energy gains the thermal efficiency is decreasing.

Results of simulation studies show the opposite situation in the distribution of electrical efficiency to distribution of thermal efficiency of the considered $\mathrm{PV} / \mathrm{T}$ modules. Electrical efficiency is the highest in winter and the lowest in summer. The main reason for this situation is the low temperature of the $\mathrm{PV} / \mathrm{T}$ modules in winter. 


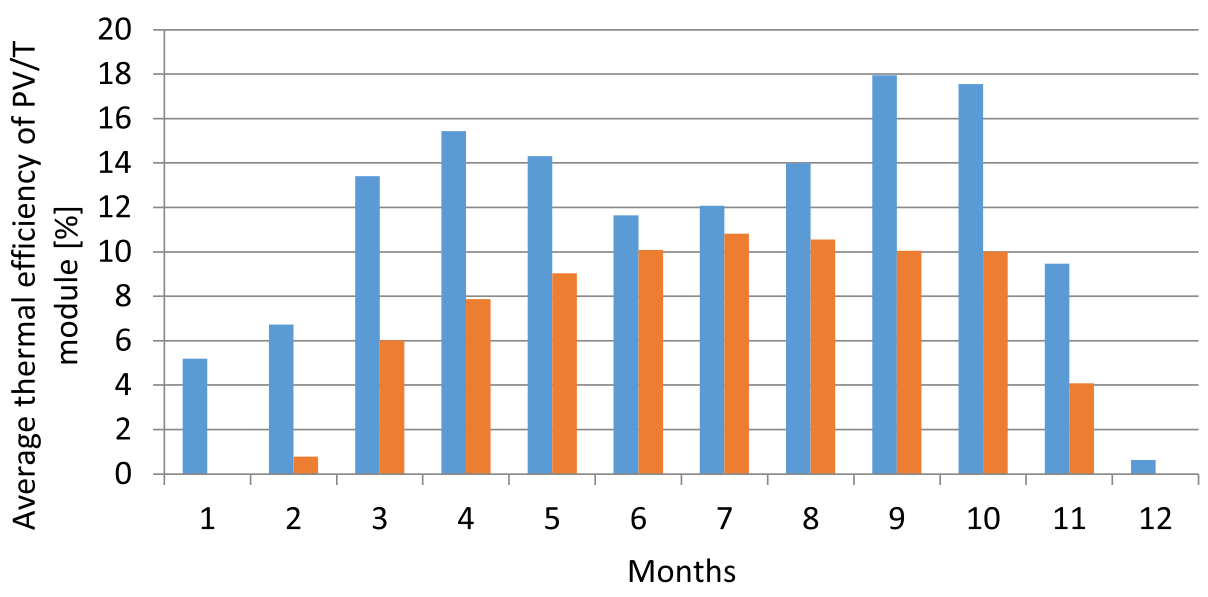

PV/T glazed

PV/T unglazed

Fig. 7. The average monthly thermal efficiency of $\mathrm{PV} / \mathrm{T}$ modules.

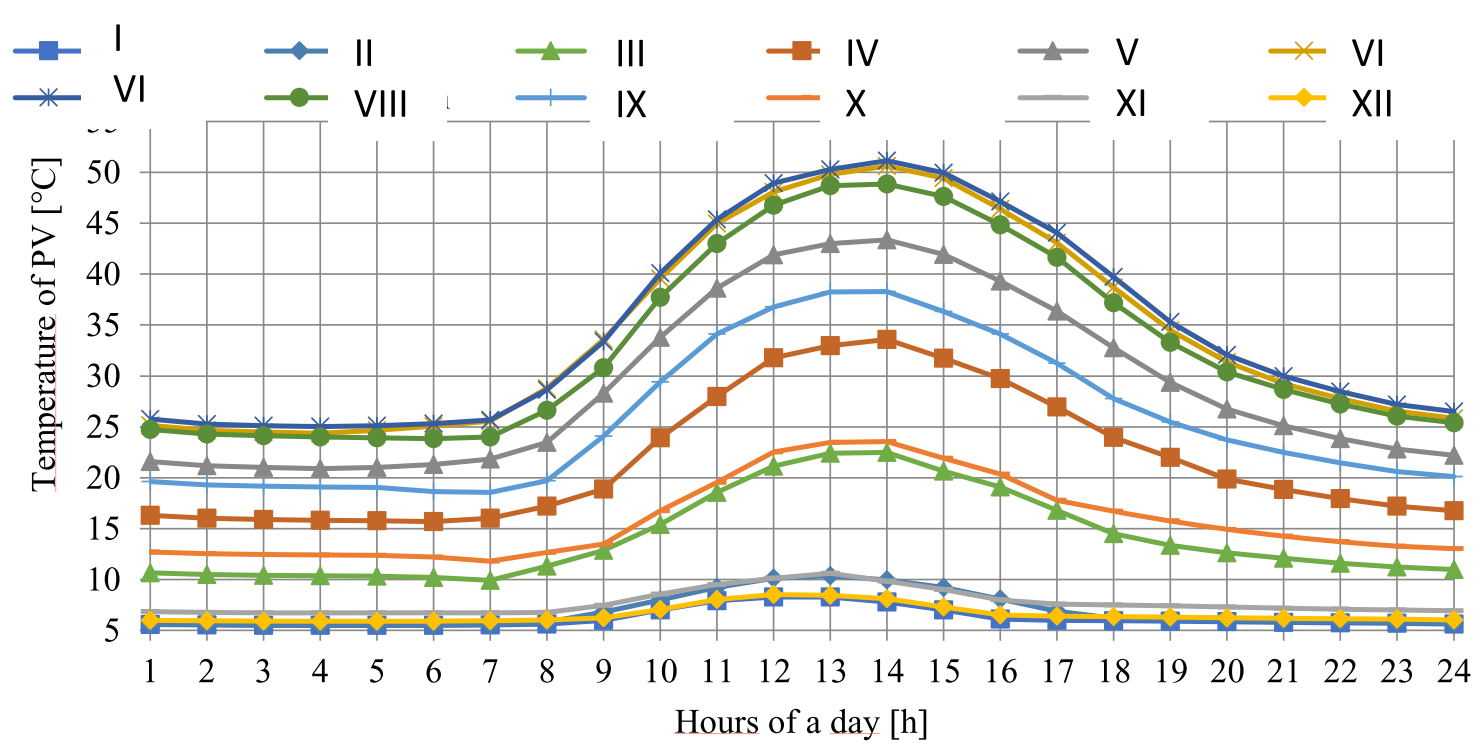

Fig. 8. Daily distribution of $\mathrm{PV}$ temperature of the $\mathrm{PV} / \mathrm{T}$ unglazed modules for average days of all months.

Figures 8 and 9 present the daily distribution of the PV temperature of the $\mathrm{PV} / \mathrm{T}$ modules for average days of all months of the averaged year for unglazed and glazed modules, respectively. As can be expected in summer the temperature of PV can grow quite high; in case of unglazed modules it can be at a level of $50{ }^{\circ} \mathrm{C}$, but in the case of glazed modules it can reach $80^{\circ} \mathrm{C}$. Analyzing Figure 8 it can be noticed that during the 6 months from April to September the temperature of $\mathrm{PV}$ in $\mathrm{PV} / \mathrm{T}$ glazed modules does not drop below $25^{\circ} \mathrm{C}$, which of course must influence the electrical efficiency of the modules.

During the 6 months of the year from October to March in the case of unglazed modules the temperature of the PV does not exceed the standard temperature of $25^{\circ} \mathrm{C}$, but in the case of glazed modules such low a temperature can be seen only for the 4 months from November till February. In December and January temperatures of both types of PV/T modules during the daytime are the same, but it is due to no operation of thermal part of $\mathrm{PV} / \mathrm{T}$ modules in both cases (very low solar radiation so too low thermal gains) and $\mathrm{PV} / \mathrm{T}$ modules operate like standard PV modules.

Figure 10 presents the average monthly electrical efficiency of $\mathrm{PV} / \mathrm{T}$ modules for all months of the year. Throughout the year the average electrical efficiency is higher for unglazed modules, in winter the difference is about $1 \%$, and for unglazed modules the efficiency reaches $12 \%$, in summer the difference is about $2 \%$, and for glazed modules the average efficiency can drop below $9 \%$.

Figure 11 shows the average efficiency for averaged day of every month, which of course is changing during the day. Referring to daily distribution of electric efficiency, in the case of unglazed $\mathrm{PV} / \mathrm{T}$ modules the highest electrical efficiency is in winter in the morning and reaches $12.2 \%$. In the case of glazed modules the electrical efficiency reaches $11.2 \%$. In summer minimal electric efficiency is at $2 \mathrm{p} . \mathrm{m}$. and for the unglazed PV/T modules it can drop to $10.1 \%$. For glazed modules it is even lower decreasing to $8 \%$. It is evident that the cover is a good solution for improving 


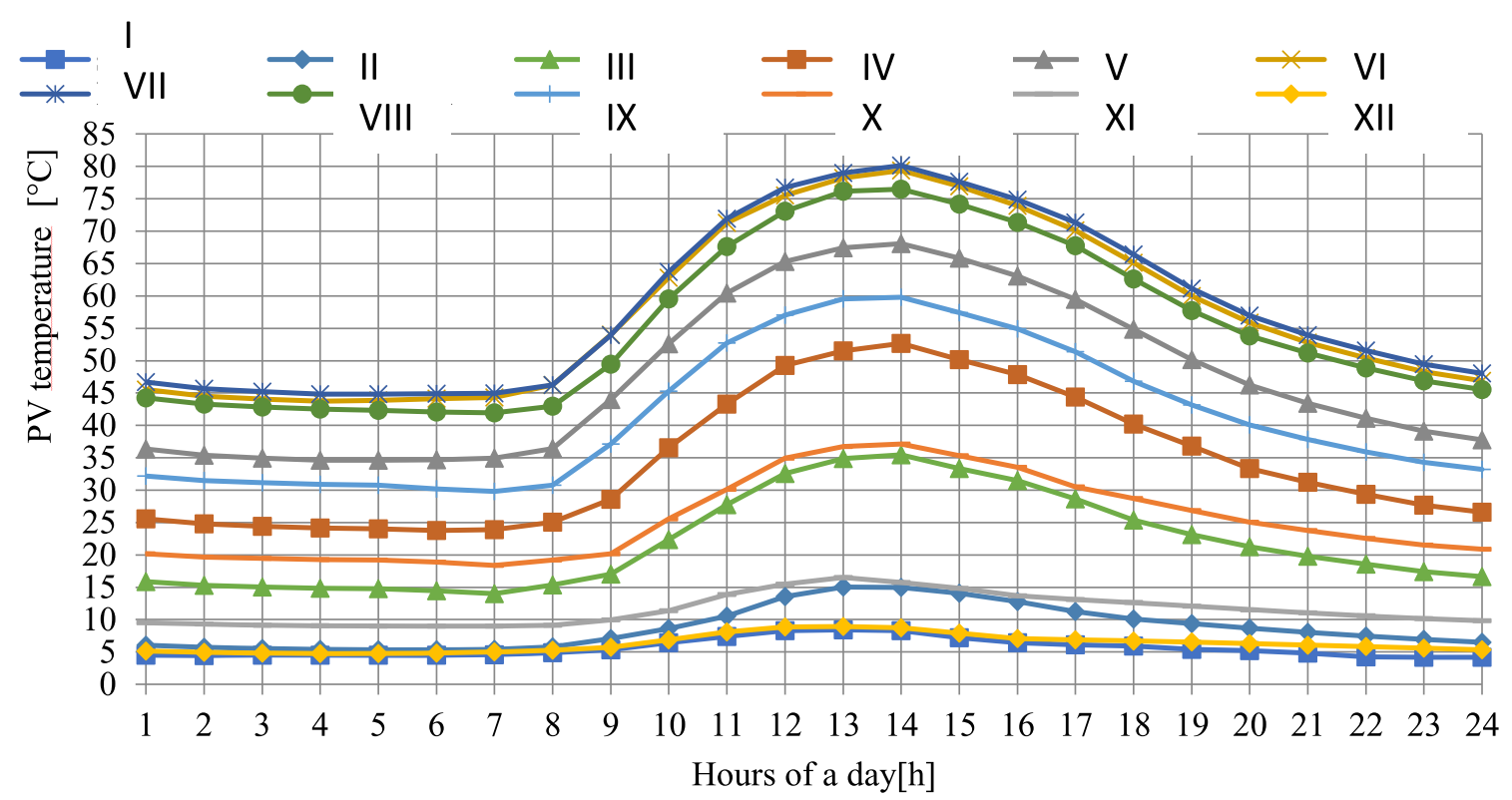

Fig. 9. Daily distribution of $\mathrm{PV}$ temperature of the $\mathrm{PV} / \mathrm{T}$ modules with covers for average days of all months.

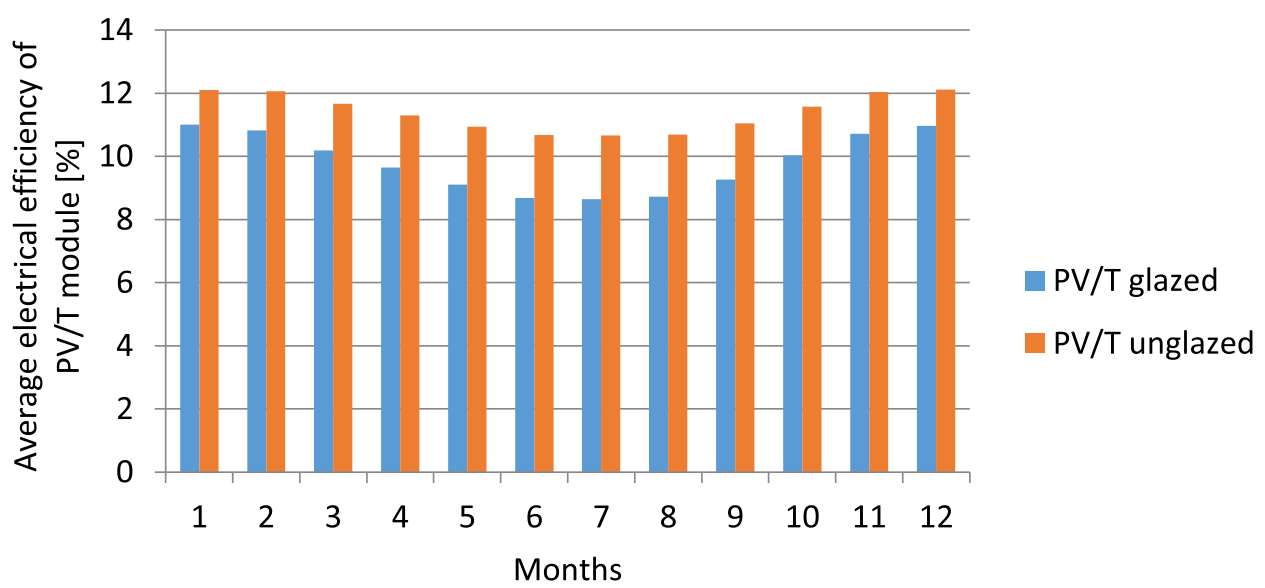

Fig. 10. The average monthly electrical efficiency of $\mathrm{PV} / \mathrm{T}$ modules.

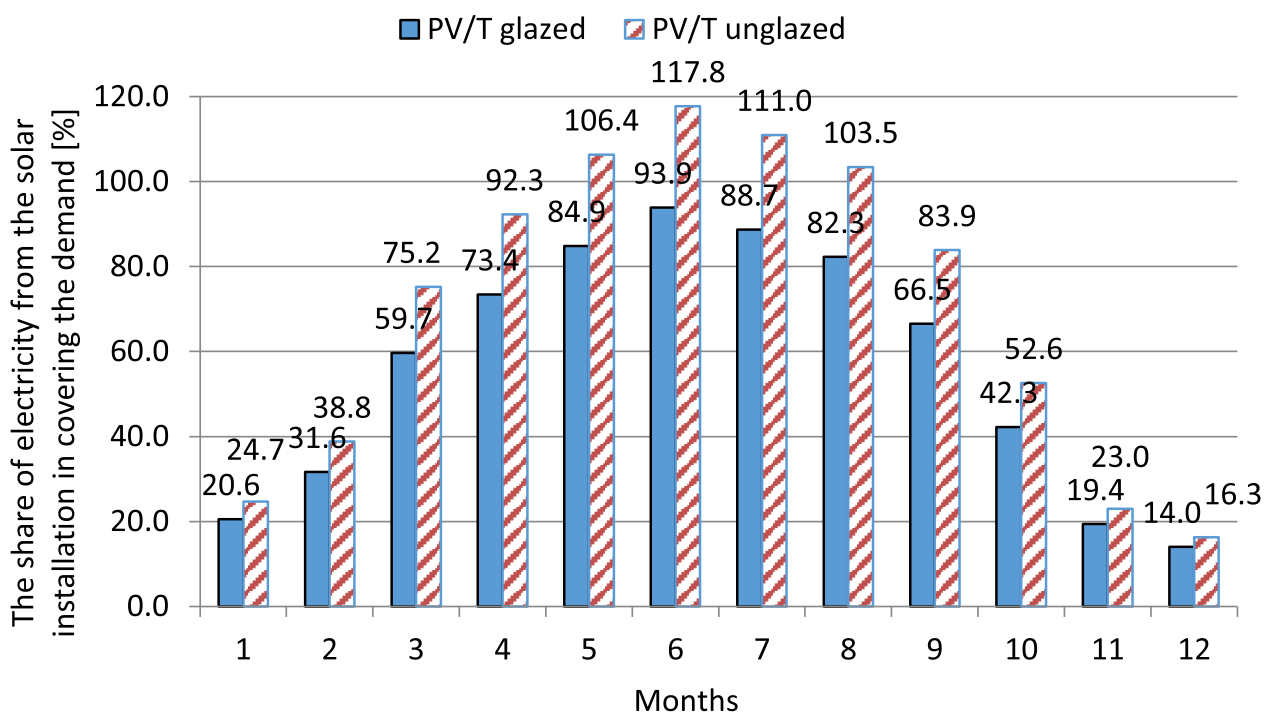

Fig. 11. Monthly share of PV electricity in providing electrical energy to a single family house for all months of the year for two cases of glazed or unglazed PV/T modules. 
thermal efficiency of the $\mathrm{PV} / \mathrm{T}$ module, but it cannot be recommended for the efficient operation of the PV cells of the module However, the efficiency cannot correspond directly to share of solar energy in providing electrical energy, as can be seen comparing Figures 10 to 11.

Analyzing Figure 11 it can be seen that the unglazed system supplies much more electricity than the glazed system. The difference is especially evident in summer. The maximum share of solar energy can be seen in June. In a case of unglazed $\mathrm{PV} / \mathrm{T}$ modules for the four months from May till August there is a surplus of energy, which is sent to the grid and can be used later since the grid is a virtual store. In the case of glazed modules there is not enough electricity produced by the system to cover all electricity demand in any month of the year. The maximal share of solar electricity, in June accounts for about 94\%, from May till the end of August this share is higher than $80 \%$. In winter the share of PV electricity can vary from $14 \%$ in December to $60 \%$ in March for glazed modules and from $16 \%$ in December to $75 \%$ in March for unglazed ones.

\section{Conclusions}

As has been mentioned, most of research studies have been already conducted for PV/T modules only. They have been focused on analysis of the operation and energy performance of the air PV/T modules, much fewer papers on the water $\mathrm{PV} / \mathrm{T}$ modules and especially on $\mathrm{PV} / \mathrm{T}$ systems as a whole. Usually in hot climate the water $\mathrm{PV} / \mathrm{T}$ modules work as the main heating devices in an open loop configuration. In such a way they limit relatively quickly the increase of temperature of the PV module. However, in central European climate the effective utilization of solar energy for heating purposes requires the use of heat storage. Consequently, the operation of the $\mathrm{PV} / \mathrm{T}$ solar system is more complex, different modes of operation are possible to provide heat or electricity, or both. Possible modes of operation have been presented in the paper and they show how complicated the energy management can be. In such a system storage processes become crucial for the effective use of solar energy and it is necessary to utilize the heat stratification effect in the storage tank.

Results show that indirect $\mathrm{PV} / \mathrm{T}$ systems can be recommended for single family houses in central European climate with some reservations. Taking into account the share of PV electricity supplied to the considered house and electrical efficiency, the unglazed $\mathrm{PV} / \mathrm{T}$ modules seem to be the most energy efficient solution. Unglazed PV/T modules can operate with relatively high electrical efficiency during the whole year and the $\mathrm{PV} / \mathrm{T}$ system with such modules provides most of electricity needs throughout the year. Systems with glazed modules have lower electrical efficiencies, especially in summer. However, the opposite situation can be noticed for the thermal efficiency and the share of solar energy supplied to a DHW heating system. Thus, thermal efficiency and the share of solar energy provided for DHW heating are larger for the glazed modules. For the considered size of the $\mathrm{PV} / \mathrm{T}$ systems and energy needs the glazed modules can fully cover the DHW demand during 5 months, from May to September, but they cannot cover the electricity demand. During these 5 months the share of electricity provided by PV can vary from $67 \%$ to $93 \%$. On the contrary, the share of thermal demand provided by the unglazed PV/T system during the same five months cannot be covered fully and varies from $62 \%$ to $90 \%$. However, the electricity demand from May until the end of August can by covered fully because, as has been mentioned above, the grid is treated as virtual storage of electricity.

It can be concluded that if electricity production is a priority then it is better to use unglazed $\mathrm{PV} / \mathrm{T}$ modules. In winter both types of the $\mathrm{PV} / \mathrm{T}$ modules: glazed and unglazed hardly supply thermal energy at all. So a good solution is to apply $\mathrm{PV} / \mathrm{T}$ modules without covers for the whole year operation and in addition a regular solar active system with standard glazed solar collectors dimensioned accordingly to DHW demand to provide the rest of DHW needs for summer time. In this case water can be used in the $\mathrm{PV} / \mathrm{T}$ modules as a working fluid and antifreeze mixture in standard glazed solar collectors loops. So it is recommended to couple the $\mathrm{PV} / \mathrm{T}$ unglazed modules in a $\mathrm{PV} / \mathrm{T}$ system designed to cover all electricity demand in summer with standard glazed solar thermal collectors to cover globally, i.e., with support of the PV/T unglazed modules, the total DHW heating demand in summer.

The $\mathrm{PV} / \mathrm{T}$ modules considered in the paper are insulated at the rear side and can be insulated (glazed) or not (unglazed) at the front. On basis of studies already developed for solar thermal collectors working in high latitude countries and according to the European standards for solar thermal collectors and heating systems, solar thermal collectors must be insulated at the rear side, if they are designed to operate the whole year. Without insulation during spring and autumn solar gains for the water heating (DHW) gained by the PV/T system would be very small and nearly no heat would be gained in winter. In case of the $\mathrm{PV} / \mathrm{T}$ module it is much better not to use the front transparent cover to reduce heat losses rather than not to use insulation at the rear. Lack of cover increases heat losses, but there are no optical losses at (through) the cover, which is beneficial of course.

In central European climate, supplying thermal energy can have the same priority as supplying electricity. Therefore optimization analysis of sizing the unglazed $\mathrm{PV} / \mathrm{T}$ modules versus standard glazed solar thermal collectors in $\mathrm{PV} / \mathrm{T}$ systems is necessary. When the glazed $\mathrm{PV} / \mathrm{T}$ modules are to be used then it is necessary to assure any large heating needs in summer, e.g., for swimming pools, underground thermal energy storage, etc.

The average annual thermal efficiency of the $\mathrm{PV} / \mathrm{T}$ module is equal to $11.5 \%$ and $6.6 \%$ in a case of glazed and unglazed modules, respectively. The average annual share of solar energy in providing heat to the DHW system accounts to $61.7 \%$ and $42.4 \%$ for these two types of PV/T modules. The stratification effect is also important for achieving better energy system performance. Therefore, simulation studies have been developed for the $\mathrm{PV} / \mathrm{T}$ system operating in the same climatic conditions and the same pattern of use the DHW and electricity, but with water in the storage tank fully mixed (no stratification 
effect). In this case the average annual share of solar energy in supplying heat to DHW system was equal to $55.7 \%$ and $35 \%$, respectively. The stratification effect is positive for the thermal energy gains of the system. Solar collectors are supplied by water from the lowest layer of the tank of the lowest temperature and as a result the temperature of water in the solar collector is low (lower than in case of a tank with fully mixed water), so heat losses to ambient air are lower and useful energy gains are high. Such a situation is also beneficial for the PV operation, because the flowing water of low temperature better cools the PV cells. In case of the glazed and unglazed $\mathrm{PV} / \mathrm{T}$ modules the average annual electrical efficiency is equal to 9.82 and $11.4 \%$, respectively. The average annual share of solar energy in providing electricity to the user (including storage in a grid) is equal to $56.6 \%$ and $67 \%$, respectively.

Summarizing, total average annual energy efficiency (thermal plus electrical) of the $\mathrm{PV} / \mathrm{T}$ modules is equal to $21.32 \%$ and $18 \%$ in a case of glazed and unglazed modules, respectively. The average annual share of solar energy in providing total energy demand, i.e., heating energy for the DHW system and electricity (including storage in a grid) is equal to $59.15 \%$ and $54.8 \%$, respectively. $\mathrm{PV} / \mathrm{T}$ technology can assure more efficient operation of the PV modules if they are cooled during their operation, which in a central Europe is mainly needed in summer and spring. There is a need for further simulation studies and experimental verification of results to formulate detailed recommendations.

\section{References}

1. S. Nižetić, D. Čoko, A. Yadav et al., Water spray cooling technique applied on a photovoltaic panel: the performance response, Energy Convers. Manag. 108, 287-296 (2016)

2. F. Schiro, A. Benato, A. Stoppato et al., Improving photovoltaics efficiency by water cooling: Modelling and experimental approach, Energy 137, 798-810 (2017)

3. Z. Zapałowicz, W. Zenczak, The possibility to improve energy efficiency through the application of PV installation including cooling modules, Renew. Sustain. Energy Rev. 143, 110964 (2021)

4. P. Atkin, M.M. Farid, Improving the efficiency of photovoltaic cells using PCM infused graphite and aluminum fins, Solar Energy 114, 217-228 (2015)

5. H.M.S. Bahaidarah, A.A.B. Baloch, P. Gandhidasan, Uniform cooling of photovoltaic panels: a review, Renew. Sustain. Energy Rev. 57, 1520-1544 (2016)

6. H. Chen, X. Chen, S. Li, Comparative study on the performance improvement of photovoltaic panel with passive under natural ventilation, Int. J. Smart Grid Clean Energy 3, 374-379 (2014)

7. J. Siecker, K. Kusakana, B.P. Numbi, A review of solar photovoltaic systems cooling technologies, Renew. Sustain. Energy Rev. 79, 192-203 (2017)

8. P. Huen, W.A. Daoud, Advances in hybrid solar photovoltaic and thermoelectric generators, Renew. Sustain. Energy Rev. 72, 1295-1302 (2017)

9. H. Najafi, K.A. Woodbury, Optimization of a cooling system based on Peltier effect for photovoltaic cells, Solar Energy 91, 152-160 (2013)
10. M.C. Browne, B. Norton, S.J. McCormack, Phase change materials for photovoltaic thermal management, Renew. Sustain. Energy Rev. 47, 762-782 (2015)

11. M.C. Browne, B. Norton, S.J. McCormack, Heat retention of a photovoltaic/thermal collector with PCM, Solar Energy 133, 533-548 (2016)

12. S.S. Chandel, T. Agarwal, Review of cooling techniques using phase change materials for enhancing efficiency of photovoltaic power systems, Renew. Sustain. Energy Rev. 73, 1342-1351 (2017)

13. A. Machniewicz, D. Knera, D. Heim, Effect of transition temperature on efficiency of PV/PCM panels, Energy Proc. 78, 1684-1689 (2015)

14. R. Stropnik, U. Stritih, Increasing the efficiency of PV panel with the use of PCM, Renew. Energy 97, 671-679 (2016)

15. M. Wolf, Performance analyses of combined heating and photovoltaic power systems for residences, Energy Convers. 16, 79-90 (1976)

16. E.C. Kern, M.C. Russel, Combined photovoltaic and thermal hybrid collector systems, in Photovoltaic Specialists Conference 13th, D.C. Washington, 1978; Conference Record. (A79-40881 17-44) New York, Inst. of Electrical and Electronics Engineers; $1153-1157$

17. S.D. Hendrie, Evaluation of combined photovoltaic/thermal collectors, in Proceedings of the Silver Jubilee Congress, Atlanta, Ga (A80-3340 1 13-44), (Pergamon Press, 1979), Vol. 3, pp. 1865-1869

18. L.W. Florschuetz, Extension of the Hottel-Whillier model to the analysis of combined photovoltaic/ thermal flat plate collectors, Solar Energy 22, 361-366 (1979)

19. J.A. Duffie, W.A. Beckman, Solar Engineering of Thermal Processes, Wiley, Hoboken, New Jersey, 2013

20. P. Raghuraman, Analytical predictions of liquid and air photovoltaic/thermal, flat-plate collector performance, J. Solar Energy Eng. 103, 291-298 (1981)

21. C.H. Cox, P. Raghuraman, Design considerations for flatplate-photovoltaic/thermal collectors, Solar Energy 35, 227-241 (1985)

22. A. Braunstein, A. Kornfeld, On the development of the solar photovoltaic and thermal (PVT) collector, IEEE Trans. Energy Convers. EC-1, 31-33 (1986)

23. B. Lalović, Z. Kiss, H. Weakliem, A hybrid amorphous silicon photovoltaic and thermal solar collector, Solar Cells 19, 131-138 (1986)

24. D.J. Mbewe, H.C. Card, D.C. Card, A model of silicon solar cells for concentrator photovoltaic and photovoltaic/thermal system design, Solar Energy 35, 247-258 (1985)

25. A. Akbarzadeh, T. Wadowski, Heat pipe-based cooling systems for photovoltaic cells under concentrated solar radiation, Appl. Thermal Eng. 16, 81-87 (1996)

26. Y. Tripanagnostopoulos, Photovoltaic/thermal solar collectors in comprehensive renewable energy, in Solar Thermal Systems, edited by S. Kalogirou (Elsevier, 2012), Vol. 3, pp. 255-300

27. K. Sopian, K.S. Yigit, H.T. Liu et al., Performance analysis of photovoltaic thermal air heaters, Energy Convers. Manag. 37, 1657-1670 (1996)

28. H.P. Garg, R.S. Adhikari, Conventional hybrid photovoltaic/thermal $(\mathrm{PV} / \mathrm{T})$ air heating collectors: steady-state simulation, Renew. Energy 11, 363-385 (1997)

29. J.K. Tonui, Y. Tripanagnostopoulos, Improved PV/T solar collectors with heat extraction by forced or natural air circulation, Renew. Energy 32, 623-637 (2007) 
30. Y. Tripanagnostopoulos, M. Souliotis, R. Battisti et al., Performance, cost and life-cycle assessment study of hybrid PVT/air solar systems, Progr. Photovolt. Res. Appl. 14, 65-76 (2006)

31. E. Sakellariou, P. Axaopoulos, An experimentally validated, transient model for sheet and tube PVT collector, Solar Energy 174, 709-718 (2018)

32. M.S. Hossain, A.K. Pandey et al., Thermal performance analysis of parallel serpentine flow based photovoltaic/ thermal $(\mathrm{PV} / \mathrm{T})$ system under composite climate of Malaysia, Appl. Thermal Eng. 153, 861-871 (2019)

33. M. Herrando, A. Ramos, I. Zabalza, C.N. Markides, A comprehensive assessment of alternative absorber-exchanger designs for hybrid PVT-water collectors, Appl. Energy 235, 1583-1602 (2019)

34. Y. Zhang, Ch. Shen, Ch. Zhang, G. Lv, Ch. Sun, D. Chwieduk, The study of heat control on PVT modules with a new leaf-like heat exchanger, J. Renew. Sustain. Energy 13, 023703 (2021)

35. A. Mellor, D. Alonso, I. Guarracino, A. Ramos et al., Roadmap for the next-generation of hybrid photovoltaic-thermal solar energy collectors, Solar Energy 174, 386-398 (2018)

36. P. Gang, F. Huide, J. Jie et al., Annual analysis of heat pipe $\mathrm{PV} / \mathrm{T}$ systems for domestic hot water and electricity production, Energy Convers. Manag. 56, 8-21 (2012)

37. M. Herrando, C.N. Markides, K. Hellgardt, A UK-based assessment of hybrid PV and solar-thermal systems for domestic heating and power: system performance, Appl. Energy 122, 288-309 (2014)

38. M. Herrando, C.N. Markides, Hybrid PV and solar-thermal systems for domestic heat and power provision in the UK: techno-economic considerations, Appl. Energy 161, 512-532 (2016)

39. Ch. Lamnatou, G. Notton, D. Chemisana, Ch. Cristofari, Storage systems for Building-Integrated Photovoltaic (BIPV) and Building-Integrated Photovoltaic/Thermal (BIPVT) installations: environmental profile and other aspects, Sci. Total Environ. 699, 134269 (2019)

40. D. Chwieduk, J. Bigorajski, Analysis of thermal and electrical efficiency of photovoltaic/ thermal - $\mathrm{PV} / \mathrm{T}$ modules operating in moderate climate at microscale. HTRES2018- Heat Transfer Renewable Energy Sources 2018, E3S Web Conf. (2018)

41. J. Bigorajski, D. Chwieduk, Analysis of a micro photovoltaic/ thermal - PV/T system operation in moderate climate, Renew. Energy 137, 127-136 (2019)

42. J. Fan, S. Furbo, Thermal stratification in a hot water tank established by heat loss from the tank, Solar Energy 86, 3460-3469 (2012)

43. E. Fuentes, L. Arce, J. Salom, A review of domestic hot water consumption profiles for application in systems and buildings energy performance analysis, Renew. Sustain. Energy Rev. 81, 1530-1547 (2018)

Cite this article as: Dorota Chwieduk, Jaroslaw Bigorajski, Some Aspects of Photovoltaic/Thermal Systems Operation in Central European Climate, Renew. Energy Environ. Sustain. 6, 37 (2021) 